\title{
Factors Influencing Usage of Social Media among Students for Academic Purposes- A Case Study in Begum Rokeya University, Rangpur, Bangladesh
}

\author{
Thasnim Humida ${ }^{1}$, Md Habib Al Mamun ${ }^{2}$ \\ ${ }^{I}$ Department of Mass Communication and Journalism, Begum Rokeya University, Rangpur, Bangladesh \\ ${ }^{2}$ School of Computer Sciences, Universiti Sains Malaysia, Minden 11800, Penang, Malaysia \\ DOI: https://dx.doi.org/10.47772/IJRISS.2021.5419
}

\begin{abstract}
The objective of this study is to explore significant factors affecting behavioral intention and actual use of social media by the university students for educational purposes. Technology acceptance model (TAM) was employed as a research framework in this study. The study examined the research framework by structural equation modeling (SEM). The framework was experimented with the data obtained from 142 students of Begum Rokeya University, Rangpur, Bangladesh. The findings of this research suggested that a) attitude(AT) and perceived usefulness(PU) have a direct and positive influence on behavioral intention(BI) to use social media by students for academic purposes, b) perceived usefulness ( $P U$ ) and perceived ease of use(PEOU) have a direct influence on Attitude (AT) to use social media by students for academic purposes, and c) behavioral intention(BI) significantly influence on Actual System Use (AU) to use social media by students for academic purposes. The findings have a practical implication for educational institution to enhance the effective use of social media among the students for various educational purposes.
\end{abstract}

Keyword: TAM, Social Media, Behavioral Intention, Actual System Use, Internet

\section{INTRODUCTION}

\subsection{Background}

Today, social media has become an indispensable part of our everyday lives. Over the last decade, the exponential growth of social media has revolutionized the way we live. It is now widely used media not only among working people but also among students. In Bangladesh, more or less 40 million people have been using social media. Most university-level students have at least one social media account like Facebook, Twitter, Instagram, YouTube, etc. Students not only use this social media for entertainment, but also, they have been using it for their academic purposes. Students are now more into participatory digital culture. Social media allow students to obtain more helpful information and connect with learning groups, making education more convenient. Social media enable students, faculty, and institutions to build an educational community to share information and resources. Although the use of social media for academic purposes is prevalent in the developed world, however, this concept is largely new in Bangladesh. Therefore, this new innovative approach will undoubtedly pose a challenge to students in terms of the effective use of social media in the academic space. Hence, it is essential to understand certain factors that would influence the acceptance of social media among students for educational purposes.

\subsection{Problem Statement and Objectives:}

Two problems led the authors to do this research- a) deficiency of investigation concerning the factors affecting the use of social media for academic purposes among students and b) lack of framework examining the factors that influence user behavioural intent and actual use toward adopting social media, especially for educational reasons among university students. In the current study, Technology Acceptance Model (TAM) is used as a research framework, because it is one of the best frameworks for investigating factors that influence users' behavioral intent toward adopting a particular technology application. TAM suggests that when people are faced with a recent technology, the decision to accept or deny them depends on several factors. TAM can investigate how user's perception affect the intention to use a technology or actual use a technology. The objective of this study is to find significant factors affecting behavioral intent and actual use of social media for academic purposes.

\section{LITERATURE REVIEW}

\subsection{Concept of Social Media}

Social media is currently being considered as a major component of internet usage. Even in the case of research, social media is becoming increasingly popular over the internet among researchers. Since the social media is changing rapidly in terms of its characteristics, it would hardly provide a proper definition. In 2008, Leader-Chivée \& Cowan referred social media to the fundamental nature of 'Web 2.0' which pointed out a switch in user proclivity and movement regarding online self-publishing and content collaboration(Leader-Chivée \& Cowan, 2008). Kaplan \& Haenlein defined social media as a type of Internet-based applications framed on the philosophical and technological underpinnings of Web 2.0. Social media facilitate consumers to produce and share the self-generated content (Kaplan \& Haenlein, 2010).Henderson et al also referred to the social media as Web 2.0. Social media is pooled of internet-based 
applications that accentuate user involvement, content generation, connectivity, and information sharing(Henderson \& Bowley, 2010). Recently, Sloan et al described social media as online based services which permit users, groups and institution to work together, unite, cooperate, and make community by creating, modifying, engaging user generated content(Sloan \& Quan-Haase, 2017). In a study, Carr and Hayes mentioned some contemporary examples of what social media is and what is not, exhibited in the below Table-1(Carr \& Hayes, 2015).

Table 1: Current Examples of Social Media Derived from Carr and Hayes' Definition

\begin{tabular}{|c|c|}
\hline Social Medium & Not a Social Medium \\
\hline $\begin{array}{l}\text { - Social network sites (e.g., Facebook, QQ, Google+, YouTube, } \\
\text { Yelp, Pheed) } \\
\text { - Professional network sites (e.g., Linkedln, IBM’s Beehive) } \\
\text { - Chatboards \& discussion fora } \\
\text { - Social/Casual games (e.g., Farmville) } \\
\text { - Wiki "Talk” pages } \\
\text { - Tinder } \\
\text { - Instagram } \\
\text { - Wanelo } \\
\text { - Yik Yak }\end{array}$ & $\begin{array}{l}\text { - Online news services (e.g., NYT online, } \\
\text { PerezHilton.com) } \\
\text { - Wikipedia } \\
\text { - Skype } \\
\text { - Netflix } \\
\text { - E-mail } \\
\text { - Online news } \\
\text { - SMS/Texts } \\
\text { - Oovoo } \\
\text { - Tumblr } \\
\text { - Whisper }\end{array}$ \\
\hline
\end{tabular}

Fred Cavazza, a French consultant, fragmented social media into ten clusters in his 'social media landscape'. The below Figure-1 exhibited the categories- publishing tools, sharing tools, discussion tools, social networks, micro-publishing tools, social aggregation tools, life, virtual worlds, social games, and massively multiplayer online games (Cavazza, 2008)

\section{Social Media Landscape}

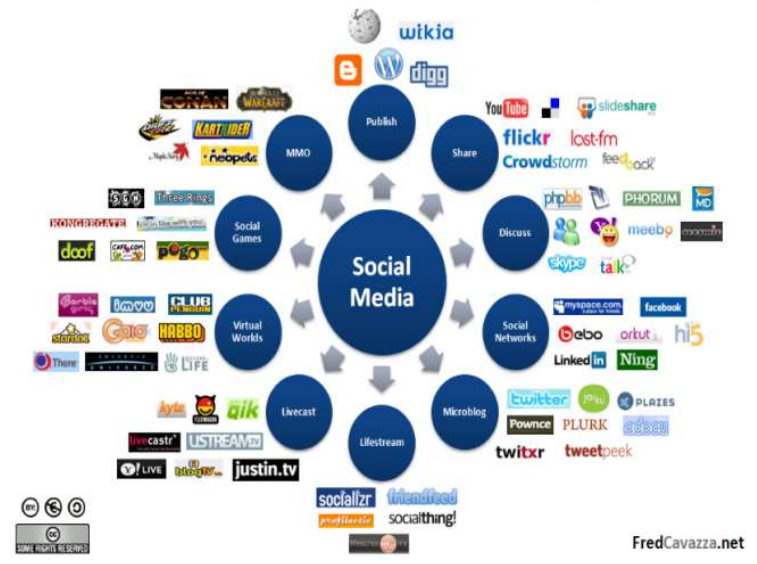

Figure 1: Social Media Landscape

\subsection{Social Media for Academic Purposes}

These days, the use of social media for academic purposes is being observed among students in universities worldwide. The effect of social media on learning and its influencing factors are now widely discussed. Presently, number of studies determining the effect of social media among university students is also increasing (Greenhow et al., 2020; Manca, 2020; Pimmer \& Rambe, 2018). Much of those studies investigated social media tools discretely for academic reasons like Facebook, Twitter or YouTube. A group of researchers has demonstrated that social media not only strengthens the interaction between students and teachers, but also reinforces the evidence base learning environment(Zheng et al., 2015). A symmetrical research in tertiary level education revealed that students are more receptive in the direction of using Facebook along with other social media platforms with greater propensity to enhance learning process compared to others who are using conventional learning techniques(Roblyer et al., 2010).

But even then, there are plenty of hurdles being seen in the way of adopting social media among students for their education. A study, investigating the impact of social media in university level learning, found that teachers are not skilled enough at utilizing social media for educational reasons, though most of the universities have enough infrastructure to do it simpler for their students to utilize the social media for their studies(Tess, 2013). Another study found that as an unofficial learning tool, the acceptance of social media is increasing among university students, however, as a formal tool, the adoption of social media by institutions is still encircled due to deficiency of proper implementation models and framework(Chawinga, 2017).

To encapsulate social media successfully for academic purpose, it is essential to perceived how it is being utilized in an educational institution(Al-Rahmi et al., 2018). Therefore, there is no other way but to investigate the pertinent studies for consolidating the knowledge and pinpointing the major factors that steered the social media in academic sphere. However, a lot of research such as (Aborujilah et al., 2017; Neier \& Zayer, 2015) has been found examining students' opinions concerning social media use on education those were not enough for determining the factors influencing usage of social media among students for academic purposes. Thus, a group of researchers recommended empirical studies for finding numerous factors affecting the use of social media in the academic field(Rahman et al., 2020; Stathopoulou et al., 2019). Recently, Hamadi et al. introduced a framework in an empirical study to determine the factors concerning social media acceptance in higher education(Hamadi et al., 2021)

\section{RESEARCH MODEL AND HYPOTHESIS}

\subsection{Research Model}

In 1989, Fred D. Davis instituted an Information system theory termed Technology Acceptance Model (TAM) which demonstrates how individuals acknowledge and use a technology (Davis, 1989). TAM is an adopted and extending idea of Theory of Reasoned Action (TRA) introduced by Fishbein and Ajzen in 1975(Fishbein \& Ajzen, 1975). The below Figure 2 exhibited the TAM model. 


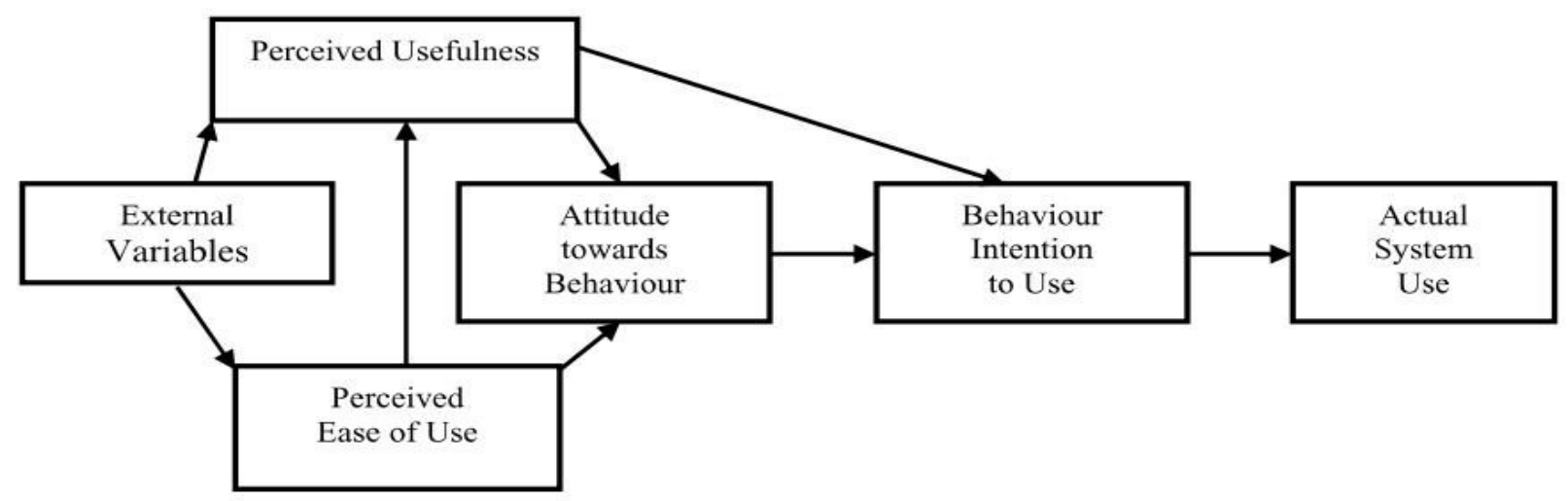

Figure 2: Technology Acceptance Model(Davis et al., 1989)

TAM includes two primary factors which influence user's intention to use new technology- a) Perceived Usefulness, and b) Perceived Ease of Use. Davis described Perceived Ease of Use as the intensity, users think that they can run a specific setup effortlessly (Davis et al., 1989). If a user perceives a system or technology is easy to operate, then the level of Perceived Ease of Use increases. Therefore, the acceptance and usage of those systems will also be high among students. Perceived usefulness is also a major factor which has an immediate influence on student's behavioural intention. Davis categorized PU as the level to which a user thinks that running a system would enhance one's performance (Davis et al., n.d.). Masrom, Venkatesh and Morris emphasized that PU has a positive and considerable impact on users behaviour which control intent of users to use a technology (Masrom et al., 2007; Venkatesh \& Morris, 2000). Additionally, several studies have discovered the reciprocal relationship among perceived ease of use, perceived usefulness and behaviral intention (Davis, 1989; Davis et al., 1989). There is a lot of distinct interpretation of the concept of behavioural intention. Fishbein and Ajzen described that behavioral intention is a subjective probability of how a person will perform the behaviour (Fishbein \& Ajzen, 1975) (Ajzen \& Fishbein, 1980). Warshaw and Davis claimed that the meaning of intention varies as it is using in regular dialect. They classified behavioral intention as the level to which an individual has made deliberate strategies to perform or not to perform certain imminent behaviour(Fishbein \& Ajzen, 1975). The below Figure 3 portrays the original theoretical framework which demonstrates actual use of the system is determined by behavioral intention to use a particular system. One hand, behavioral intention directly determined by users' attitude towards using the sytem, on the other hand, behavioral intention and perceived usefulness jointly influence towards actual use of a system. The below model presented in Figure 3 has been used as the research model for this study.

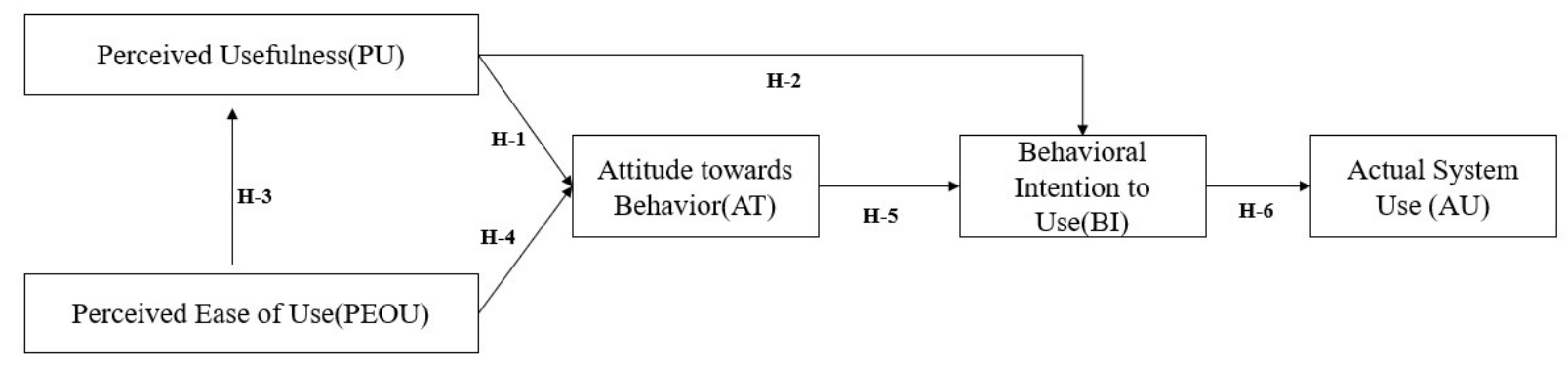

Figure 3: Research Model based on Original TAM

\subsection{Research Variable and Hypothesis:}

For this study, TAM was used as the research framework and all five variables from TAM were used to build the hypothesis. The below Table 2 presented the name and acronym of each TAM variable.
Table 2: Research variable name and acronym

\begin{tabular}{|c|c|}
\hline Name of variable & Acronym of variable \\
\hline Perceived usefulness & PU \\
\hline Perceived ease of use & PEOU \\
\hline Attitude towards behavior & AT \\
\hline Behavioral intention to use & BI \\
\hline Actual system use & AU \\
\hline
\end{tabular}


H-1: Perceived Usefulness (PU) has a direct influence on Attitude (AT) to use social media by students for academic purposes.

$H-2$ : Perceived Usefulness (PU) positively and significantly influence on behavioral intention (BI) to use social media by students for academic purposes.

H-3: Perceived Ease of Use (PEOU) has direct influence on Perceived Usefulness (PU) to use social media by students for academic purposes.

H-4: Perceived Ease of Use (PEOU) has direct influence on Attitude (AT) to use social media by students for academic purposes.

H-5: Attitude (AT) has direct influence on behavioral intention (BI) to use social media by students for academic purposes.

H-6: Behavioral intention (BI) has direct influence on Actual System Use (AU) to use social media by students for academic purposes.

\section{RESEARCH METHODOLOGY}

In this study, a quantitative method was employed to examine the factors influencing the use of social media among students for educational reason using the formulated hypothesis and research model. The sample of this research incorporated undergraduate and postgraduate students at Begum Rokeya University, Rangpur (BRUR) in Bangladesh. The questionnaire was prepared in English and designed in Google Form. And then it was distributed randomly through online to a total 300 students, out of which the researchers received 220 resulting $73 \%$ of response rate. 78 forms were discarded because of insufficient data. The questionnaires were formed based on earlier research. However, it was reformed to make appropriate the purpose of this study. A total of 23 questions were divided into three sections- a) section one consisted 3 demographic questions, b) section two composed 5 questions about experiences of using the internet and smartphone, and c) section three accumulated 15 assessment questions. The questions of the assessment section represented five constructa) Perceived Usefulness (PU), b) Perceived Ease of Use (PEOU), c) Attitude (AT), d) Behavioural Intention (BI), and e) Actual Use (AU). A 5-point Likert scale stretched from 1 to 5(strongly disagree to strongly agree) was used to measure the assessment questions. For analysing demographic figure, internet and smart phone experiences, and descriptive statistics, the study used IBM SPSS software. SMARTPLS3 was used for the application of SEM technique to study the research model and hypothesis.

\section{DATA ANALYSIS AND DISCUSSION}

\subsection{Demographics and Experiences}

The online survey was conducted on 300 students who are studying at Begum Rokeya University. Of these, 220 students participated in the survey. 78 forms were canceled due to incomplete responses. In the end, 142 of the forms $(64.55 \%)$ were used for the data analysis of this study. At first, the research analyzed the demographic profile of respondents by IBM SPSS software. The Table 3 demonstrated that more than $67 \%$ of the students participating in the survey were male whereas only around $32 \%$ of female. Among the attendees, the predominance of age group below 25 years was found to be higher, around $90 \%$. Similarly, the participation of graduate first year students was seen to be higher, more than $35 \%$.

Table 3: Demographic Profile of Respondents

\begin{tabular}{|c|c|c|}
\hline Demographic Profile (N=142) & Frequency & $\begin{array}{c}\text { Percentage } \\
(\%)\end{array}$ \\
\hline Gender & & \\
\hline Female & 46 & 32.4 \\
\hline Male & 96 & 67.6 \\
\hline Age & & \\
\hline 26-35 & 15 & 10.6 \\
\hline Below 25 & 127 & 89.4 \\
\hline Study Year & & \\
\hline 1st Year (Bachelor) & 50 & 35.2 \\
\hline 2nd Year (Bachelor) & 14 & 9.9 \\
\hline 3rd Year (Bachelor) & 22 & 15.5 \\
\hline 4th Year (Bachelor) & 36 & 25.4 \\
\hline Masters & 20 & 14.1 \\
\hline
\end{tabular}

This section examined the data about the level of experience students possessed on social media and information technology. The below Table 4 unveiled that close to $70 \%$ of the participants have been utilizing social media for more than 3 years. Around $60 \%$ of students have at least one smartphone; the number of students having no ICT gadget is only $1.4 \%$. The analysis revealed that the use of WIFI and mobile data is the most popular among the students. The study found that $92 \%$ of students feel comfortable using social media and more than $99 \%$ of them think that social media is beneficial for academic purpose.

Table 4: Social Media \& ICT Experiences

\begin{tabular}{|c|c|c|}
\hline $\begin{array}{c}\text { Demographic Profile (N=142) } \\
\text { Student's experience level in using Social } \\
\text { Media }\end{array}$ & \multicolumn{2}{|c|}{} \\
\hline 1-3 years & 33 & 23.2 \\
\hline 3-6 years & 66 & 46.5 \\
\hline Less than 1 year & 10 & 7 \\
\hline More than 6 years & 33 & 23.2 \\
\hline Type of ICT devices owned by students & & 3.5 \\
\hline Computer/Laptop & 5 & 28.2 \\
\hline Computer/Laptop, SmartPhone & 40 & 5.6 \\
\hline Computer/Laptop, Smart Phone, Tablet & 8 & 1.4 \\
\hline None & 2 & \multicolumn{2}{|c|}{} \\
\hline
\end{tabular}




\begin{tabular}{|c|c|c|}
\hline Smart Phone & 86 & 60.6 \\
\hline Tablet & 1 & 0.7 \\
\hline Type of Internet used by students & \multicolumn{2}{|l|}{} \\
\hline Mobile Data & 58 & 40.8 \\
\hline Mobile Data, WiFi & 62 & 43.7 \\
\hline WiFi & 22 & 15.5 \\
\hline Comfortability using Social Media & \multicolumn{2}{|l}{} \\
\hline No & 11 & 7.7 \\
\hline Yes & 131 & 92.3 \\
\hline $\begin{array}{c}\text { The usefulness of Social Media for } \\
\text { educational purposes. }\end{array}$ & \multicolumn{2}{|l}{} \\
\hline No & 141 & 99.3 \\
\hline Yes & \multicolumn{2}{|l}{} \\
\hline
\end{tabular}

\subsection{Descriptive Analysis}

In order to understand the characteristics of the sample, the study analysed descriptive statistic in IBM SPSS. The result shown in the Table 5 that the mean is stretched from 3.92 to 4.11 for all five variables. The values of standard deviation ranged from 0.59 to 0.76 . The value of mean and standard error indicated that the data were distributed normally, and it was concentrated around the mean. Consequently, the data were less disseminated.

Table 5: Descriptive Statistics

\begin{tabular}{|c|c|c|c|c|c|}
\hline & PU & PEOU & AT & BI & AU \\
\hline $\mathrm{N}$ & 142 & 142 & 142 & 142 & 142 \\
\hline Mean & 3.94 & 4.11 & 3.92 & 3.92 & 4.00 \\
\hline Std. Deviation & 0.74 & 0.59 & 0.76 & 0.74 & 0.68 \\
\hline Minimum & 1.67 & 2.33 & 1.33 & 1.33 & 1.67 \\
\hline Maximum & 5.00 & 5.00 & 5.00 & 5.00 & 5.00 \\
\hline
\end{tabular}

\subsection{Measurement Model:}

In this data analysis section, convergent and discriminant validity tests were used to measure the research model. These tests were performed to examine the sufficiency of the construct used in the model.

\subsubsection{Convergent validity:}

Three measures recommended in assessing the converging validity- a) composite reliability, b) item reliability and c) average variance extracted (Fornell \& Larcker, 1981). Reliability is a test of examining the level of consistency among the variables and this evaluation must be made before examining its validity (Hair, J. F., Black, W. C., Babin, B. J., \& Anderson, 2018). to investigate the internal consistency among the constructs, the study relied on the value of Cronbach's alpha $(\alpha)$. There are four level of alpha- a) 0.90 and more denotes excellent reliability, b) 0.70 to 0.90 denotes high reliability, c) 0.50 to 0.70 denotes moderate reliability, and 0.50 and less denotes the low reliability (Hinton, P. R., Brownlow, C., McMurray, I., \& Cozens, 2014).

Table 6: Convergent validity

\begin{tabular}{|c|c|c|c|c|}
\hline & $\begin{array}{c}\text { Cronbach's } \\
\text { Alpha }(\alpha)\end{array}$ & $\begin{array}{c}\text { rho_A/Factor } \\
\text { Loading }\end{array}$ & CR & AVE \\
\hline PU & 0.752 & 0.782 & 0.859 & 0.673 \\
\hline PEOU & 0.727 & 0.751 & 0.846 & 0.650 \\
\hline AT & 0.825 & 0.832 & 0.896 & 0.741 \\
\hline BI & 0.816 & 0.818 & 0.891 & 0.731 \\
\hline AU & 0.652 & 0.658 & 0.812 & 0.591 \\
\hline
\end{tabular}

The above Table 6 demonstrated that the alpha value of all variables varied from 0.652 to 0.825 . Thus, all four showed high reliability except the AU which scored 0.652 with moderate reliability. For evaluating the item reliability, factor loading method was used. 0.5 or higher value considered as significant measurement recommended by Hair et al (Hair, J. F., Black, W. C., Babin, B. J., \& Anderson, 2018). As appeared in the above Table 6 , all the value ranged from 0.658 to 0.832 which demonstrate higher item reliability for each construct. Additionally, the AVE value of each constructs must be higher than 0.5 for being accepted (Fornell \& Larcker, 1981). The earlier Table 6 showed that all value complied the acceptance level. Thus, it is proved that every constructs of this research model were adequate.

\subsubsection{Discriminant validity:}

Discriminant validity is usually tested by squared correlations between two separate weighs in either construct and that should be less than the variance shared by the measures of a construct (Fornell \& Larcker, 1981). The following Table 7 represents that shared variance by same construct was larger than all shared variance by separate construct. The final value of each row was greater than others value in same row. Thus, the discriminant test proved that the constructs of this model did not relate highly each other.

Table 7: Discriminant validity

\begin{tabular}{|c|c|c|c|c|c|}
\hline & AT & AU & BI & PEOU & PU \\
\hline AT & 0.861 & & & & \\
\hline AU & 0.643 & 0.769 & & & \\
\hline BI & 0.688 & 0.686 & 0.855 & & \\
\hline PEOU & 0.646 & 0.675 & 0.706 & 0.806 & \\
\hline PU & 0.559 & 0.477 & 0.690 & 0.694 & 0.820 \\
\hline
\end{tabular}

\subsection{Statistical Analysis and Hypothesis Testing}

\subsubsection{Structural Model}

A structural model was built in this section to investigate the correlation among the variables. Two methods were taken in this study for evaluating the underlying model- a) hypothesis testing, and b) predictive strength testing. For testing the 
hypothesis, the study used standardize path efficient. Moreover, compute of R2 or coefficient of determination was utilized for determining the predictive strength.PLS and
Bootstrapping analysis were used in SmartPLS3 to get the result.

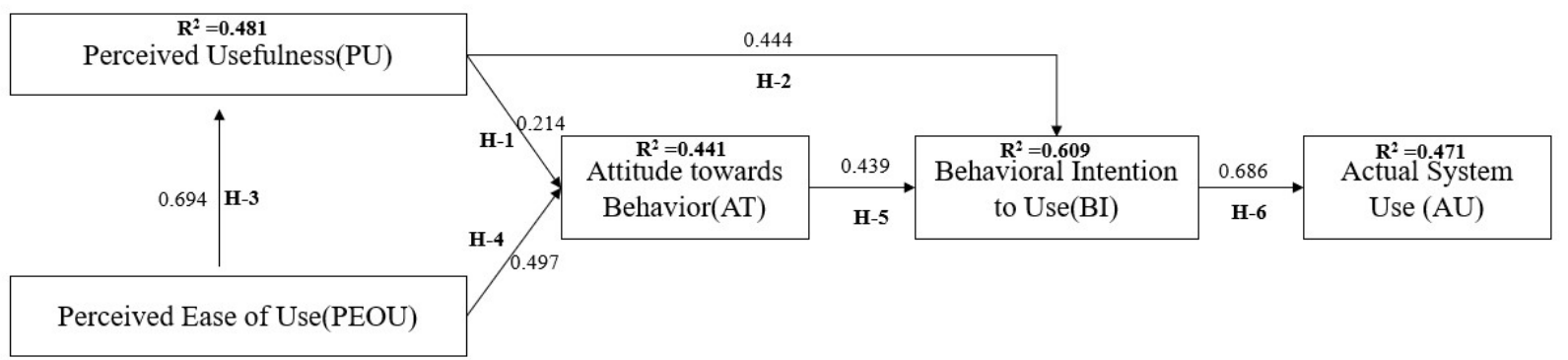

Value on path: standardized coefficients $(\beta) \quad \mathrm{R}^{2}$ : Coefficient of determination

Figure 4: Structural Model

The above Figure 4 unveiled that the R2 value for perceived usefulness (PU), attitude towards behavior (AT), and actual system use (AU) are 0.481, 0.441 and 0.471, respectively denoting a moderate effect size to predict the variable. The R2 value for behavioral intention to use (BI) is 0.609 determining a strong level of predictive power in the context of using the social media for academic purposes.

\subsubsection{Hypotheses Testing}

The following Table 8 demonstrated that all hypothesis $\mathrm{H} 1$ to H6. Because all those hypotheses have recommended reference value of $\mathrm{P}, \mathrm{T}$, and $\beta$. Perceived Usefulness (PU) $(\beta=0.214, p<0.01)$ has a direct influence on Attitude $(\mathrm{AT})$ and Perceived Usefulness (PU) $(\beta=0.444, p<0.01)$ behavioral intention (BI) to use social media by students for academic purposes. Therefore, $\mathrm{H} 1$ and $\mathrm{H} 2$ are supported. Addtionally, Perceived Ease of Use (PEOU) $(\beta=0.694, p<0.01)$ has direct influence on Perceived Usefulness (PU) and Perceived Ease of Use (PEOU) $(\beta=0.497, \mathrm{p}<0.01)$ has direct influence on Attitude towards behavior(AT) to use social media by students for academic purposes. Thus, $\mathrm{H} 3$ and $\mathrm{H} 4$ are also supported. Attitude (AT) $(\beta=0.439, \quad \mathrm{p}<0.01)$ has direct influence on behavioral intention(BI) and Behavioral intention(BI) $(\beta=0.686, p<0.01)$ has direct influence on Actual System Use (AU) to use social media by students for academic purposes.

Table 8: Result of Hypothesis

\begin{tabular}{|c|c|c|c|c|c|c|}
\hline $\begin{array}{c}\text { Hyp } \\
\text { othes } \\
\text { is }\end{array}$ & Path & Beta & $\begin{array}{c}\text { Standard } \\
\text { Error }\end{array}$ & $\begin{array}{c}\mathrm{T} \\
\text { Statisti } \\
\text { cs }\end{array}$ & $\begin{array}{c}\text { P } \\
\text { Values }\end{array}$ & $\begin{array}{c}\text { Decisio } \\
\mathrm{n}\end{array}$ \\
\hline H1 & PU -> AT & 0.214 & 0.098 & 2.176 & 0.000 & $\begin{array}{c}\text { Suppor } \\
\text { ted }\end{array}$ \\
\hline H2 & PU -> BI & 0.444 & 0.102 & 4.360 & 0.000 & $\begin{array}{c}\text { Suppor } \\
\text { ted }\end{array}$ \\
\hline H3 & $\begin{array}{c}\text { PEOU -> } \\
\text { PU }\end{array}$ & 0.694 & 0.051 & 13.637 & 0.000 & $\begin{array}{c}\text { Suppor } \\
\text { ted }\end{array}$ \\
\hline H4 & $\begin{array}{c}\text { PEOU -> } \\
\text { AT }\end{array}$ & 0.497 & 0.110 & 4.518 & 0.000 & $\begin{array}{c}\text { Suppor } \\
\text { ted }\end{array}$ \\
\hline H5 & AT -> BI & 0.439 & 0.109 & 4.019 & 0.000 & $\begin{array}{c}\text { Suppor } \\
\text { ted }\end{array}$ \\
\hline
\end{tabular}

\begin{tabular}{|c|c|c|c|c|c|c|}
\hline H6 & BI -> AU & 0.686 & 0.055 & 12.541 & 0.000 & $\begin{array}{c}\text { Suppor } \\
\text { ted }\end{array}$ \\
\hline
\end{tabular}

\section{CONCLUSION}

The study relied entirely on technology acceptance model (TAM) for examining the factors that influence the usage of social media for academic purposes among students in tertiary level institutions. The study constructed six hypotheses based on all five variables of TAM-PE, PEOU, AT, BI, and AU. The study data were gathered from 142 students from undergraduate and graduate level students from Begum Rokeya University, Rangpur, Bangladesh. The data analysis unveiled that this research model appeared as internally consistent and reliable. Thus, this research model has a high level of explanatory power. The result showed that BI and PEOU emerged as lead element that significantly influence on AU and PU respectively. AT and BU also appeared as the key factor that has also direct influence on behavioral intention in using social media for academic purposes. Finally, the statistical analysis proved that all hypotheses are supported in this study. In conclusion, the outcome of this study would play a momentous role for the institutions in making their education policy.

\section{IMPEDIMENTS AND FURTHER STUDY}

The study found some impediment that left unsolved. But this study sheds light on some of the issues that may play a role in overcoming the problems. Nowadays, technologies have been growing exponentially. Therefore, student's perception of perceived usefulness (PU), perceived ease of use (PEOU), attitude towards behavior (AT), behavioral intention to use a system (BI), and actual system use (AU) has been changing rapidly. Hence, the current approach may need revise in future research for obtaining more accurate result. The study investigated the responses from one public university for the time limitation. However, the similar study can be extended to more universities together. Finally, the research conducted 
during the pandemic situation which may affect their opinion. As a result, there was a possibility of a mistake in the result. Future research has the potential to correct all these mistakes.

\section{REFERENCES}

[1] Aborujilah, A., Nassr, R., Saadat, M. N., \& Abdullah, M. (2017, January 5). Lecturers' perception on social media networks uses in education. Proceedings of the 11th International Conference on Ubiquitous Information Management and Communication, IMCOM 2017. https://doi.org/10.1145/3022227.3022241

[2] Ajzen, I., \& Fishbein, M. (1980). Understanding Attitudes and Predicting Social Behavior. Prentice-Hall, Englewood Cliffs, NJ.

[3] Al-Rahmi, W. M., Alias, N., Othman, M. S., Marin, V. I., \& Tur, G. (2018). A model of factors affecting learning performance through the use of social media in Malaysian higher education. Computers and Education, 121, 59-72. https://doi.org/10.1016/j.compedu.2018.02.010

[4] Carr, C. T., \& Hayes, R. A. (2015). Social Media: Defining, Developing, and Divining. Atlantic Journal of Communication, 23(1), 46-65. https://doi.org/10.1080/15456870.2015.972282

[5] Cavazza, F. (2008). Social Media Landscape. https://fredcavazza.net/2008/06/09/social-media-landscape/

[6] Chawinga, W. D. (2017). Taking social media to a university classroom: teaching and learning using Twitter and blogs. International Journal of Educational Technology in Higher Education, 14(1), 3. https://doi.org/10.1186/s41239-017-0041-6

[7] Davis, F. D. (1989). Perceived usefulness, perceived ease of use, and user acceptance of information technology. MIS Quarterly: Management Information Systems, 13(3), 319-339. https://doi.org/10.2307/249008

[8] Davis, F. D., Bagozzi, R. P., \& Warshaw, P. R. (n.d.). User Acceptance of Computer Technology: A Comparison of Two Theoretical Models. Management Science, 35, 982-1003. https://doi.org/10.2307/2632151

[9] Davis, F. D., Bagozzi, R. P., \& Warshaw, P. R. (1989). User Acceptance of Computer Technology: A Comparison of Two Theoretical Models. Management Science, 35(8), 982-1003. https://doi.org/10.1287/mnsc.35.8.982

[10] Fishbein, M., \& Ajzen, I. (1975). Belief, attitude, intention, and behavior: an introduction to theory and research. AddisonWesley Pub. Co.

[11] Fornell, C., \& Larcker, D. F. (1981). Evaluating Structural Equation Models with Unobservable Variables and Measurement Error. Journal of Marketing Research, 18(1), 39. https://doi.org/10.2307/3151312

[12] Greenhow, C., Galvin, S., Brandon, D., \& Askari, E. (2020). A Decade of Research on K-12 Teaching and Teacher Learning with Social Media: Insights on the State of the Field. Teachers College Record, 122(6), 1-72.

[13] Hair, J. F., Black, W. C., Babin, B. J., \& Anderson, R. E. (2018). Multivariate Data Analysis (8th ed.). Cengage Learning EMEA.

[14] Hamadi, M., El-Den, J., Azam, S., \& Sriratanaviriyakul, N. (2021). Integrating social media as cooperative learning tool in higher education classrooms: An empirical study. Journal of King Saud University - Computer and Information Sciences. https://doi.org/10.1016/j.jksuci.2020.12.007

[15] Henderson, A., \& Bowley, R. (2010). Authentic dialogue? The role of "friendship" in a social media recruitment campaign. Journal of Communication Management, 14(3), 237-257. https://doi.org/10.1108/13632541011064517

[16] Hinton, P. R., Brownlow, C., McMurray, I., \& Cozens, B. (2014). SPSS Explained. In SPSS Explained (2nd ed.). Routledge. https://doi.org/https://doi.org/10.4324/9781315797298

[17] Kaplan, A. M., \& Haenlein, M. (2010). Users of the world, unite! The challenges and opportunities of Social Media. Business Horizons, 53(1), 59-68. https://doi.org/10.1016/j.bushor.2009.09.003

[18] Leader-Chivée, L., \& Cowan, E. (2008). Networking the way to success: online social networks for workplace and competitive advantage. People \& Strategy, 31(4), 40-46. https://search.proquest.com/openview/75baa31d4063896cb4acca0 cf5eaa8b1/1.pdf?pq-origsite $=$ gscholar\&cbl $=52465$

[19] Manca, S. (2020). Snapping, pinning, liking or texting: Investigating social media in higher education beyond Facebook. Internet and Higher Education, 44, 100707. https://doi.org/10.1016/j.iheduc.2019.100707

[20] Masrom, M., Masrom, M., \& Teknologi, U. (2007). Technology Acceptance Model and E-learning. IN 12TH INTERNATIONAL CONFERENCE ON EDUCATION, SULTAN HASSANAL BOLKIAH INSTITUTE OF EDUCATION UNIVERSITI, BRUNEI DARUSSALAM,

$21--24$. http://citeseerx.ist.psu.edu/viewdoc/summary?doi=10.1.1.554.6982

[21] Neier, S., \& Zayer, L. T. (2015). Students' Perceptions and Experiences of Social Media in Higher Education. Journal of Marketing Education, 37(3), 133-143. https://doi.org/10.1177/0273475315583748

[22] Pimmer, C., \& Rambe, P. (2018). The inherent tensions of "Instant Education": A critical review of mobile instant messaging. International Review of Research in Open and Distance Learning, 19(5), 219-237. https://doi.org/10.19173/irrodl.v19i5.3765

[23] Rahman, S., Ramakrishnan, T., \& Ngamassi, L. (2020). Impact of social media use on student satisfaction in Higher Education. Higher Education Quarterly, 74(3), 304-319. https://doi.org/10.1111/hequ. 12228

[24] Roblyer, M. D., McDaniel, M., Webb, M., Herman, J., \& Witty, J. V. (2010). Findings on Facebook in higher education: A comparison of college faculty and student uses and perceptions of social networking sites. Internet and Higher Education, 13(3), 134-140. https://doi.org/10.1016/j.iheduc.2010.03.002

[25] Sloan, L., \& Quan-Haase, A. (2017). The SAGE Handbook of Social Media Research Methods.

[26] Stathopoulou, A., Siamagka, N. T., \& Christodoulides, G. (2019). A multi-stakeholder view of social media as a supporting tool in higher education: An educator-student perspective. European Management Journal, 37(4), 421-431. https://doi.org/10.1016/j.emj.2019.01.008

[27] Tess, P. A. (2013). The role of social media in higher education classes (real and virtual)-A literature review. Computers in Human Behavior, 29(5), A60-A68. https://doi.org/10.1016/j.chb.2012.12.032

[28] Venkatesh, V., \& Morris, M. G. (2000). Why don't men ever stop to ask for directions? Gender, social influence, and their role in technology acceptance and usage behavior. MIS Quarterly: Management Information Systems, 24(1), 115-136. https://doi.org/10.2307/3250981

[29] Zheng, B., Niiya, M., \& Warschauer, M. (2015). Wikis and collaborative learning in higher education. Technology, Pedagogy and Education, 24(3), 357-374. https://doi.org/10.1080/1475939X.2014.948041 


\section{Appendix A: Instrument Development}

1. Perceived Usefulness (PU)

PU1: Using the social media would help me to know academic events more quickly.

PU2: Using the social media would increase my learning performance.

PU3: Using social media would make my academic life more convenient.

2. Perceived Ease of Use (PEOU)

PEOU1: Learning to use the social media would be easy for me.

PEOU2: I would find it easy to use the social media to do my academic tasks.

PEOU3: I find using social media require a less of physical effort.

3. Attitude towards Behavior(AT)

AT1: Using social media for academic purposes is a very innovative idea to me.

AT2: Using social media for academic purposes is a very positive idea to me.

AT3: Using social media for academic purposes is interesting to me.

4. Behavioral Intention to Use (BI)

BI1: If I had access to the social media, I intend to use it.

BI2: I intend to use the social media in the future.

BI3: I will recommend another student to use the social media.

5. Actual System Use (AU)

AU1: I use social media very frequently.

AU2: I use social media for various academic purposes.

AU3: Using social media for academic purposes is saving my time. 